\title{
DETERMINATION OF THE VALUE OF INTANGIBLE ASSETS IN THE COMPANIES OF LITHUANIA
}

\author{
Rita Bužinskienè \\ Siauliai State College,Lithuania,E-mail: ritabuzin@gmail.com
}

\begin{abstract}
In accordance with generally accepted accounting standards, most intangibles are not accounted for and not reflected in the traditional financial accounting. For this reason, most companies account intangible assets (IAs) as expenses. In the research, 57 sub-elements of IAs were applied, which are grouped into eight main elements of IAs. The classification of IAs consists in two parts of assets: accounting and non-accounting. This classification can be successfully applied in different branches of enterprises, to expand and supplement the theoretical and practical concepts of the company's financial management. The article proposes to evaluate not only the value of financial information for IAs (accounted) but also the value of non-financial information for IAs (non-accounted), thus revealing the true value of IAs that is available to the companies of Lithuania. It names a value of general IAs. The results of the research confirmed the IA valuation methodology, which allows companies to calculate the fair value of an IA. The obtained extended IAs valuation information may be valuable to both the owners of the company and investors, as this value plays an important practical role in assessing the impact of IAs on the market value of companies.
\end{abstract}

Keywords: intangible assets; financial information; non-financial information; fair value.

JEL Classification: G32

\section{Introduction}

The topicality of the research. The pace of economic growth, people's social welfare and sustainable development of the economy are increasingly dependent on the creation of new knowledge and practical application of it. The activities of the company are related to different types of resources, amongst which intangible assets (IAs) are becoming an increasingly important incentive for the company to operate. At the end of the twentieth century, the increased interest in IAs and its impact on the market value of companies encouraged companies to increase their investment in human resources, research and development, new technologies and so on. In order to maintain a competitive advantage and increase the value of shares in the market, the true value of IAs in the balance remains important, as it also determines the value of the companies on the market.

Despite the growing importance of IAs in the process of companies' value creation, most of them are not accounted for and do not reflect in traditional financial accounting. Typically, only some types of IAs are recorded in the balance sheet: goodwill, licenses, copyrights, software, development and research. Issues and uncertainties regarding the estimation of the value of IAs are still not resolved. IAs are only accounted for such resources whose costs meet the definition of IAs and recognition criteria: future economic benefits, value and control. Solving the problems of determining the value of IAs, people encounter with a lack of disclosure of accounting information. Proper disclosure of accounting information is based on fairness and equality of rights. Otherwise, incorrectly disclosed information suggests opportunities to unfair competition in the securities market. The reliability of accounting information in the quality area is ensured by external institutions that are focused on disclosure and publicity.

In principle, researchers are solving different problems: what value of IAs are disclosed in the financial statements; how the structure of IAs is changing in various industrial sectors; to what extent unrecorded IAs value exceeds the fair value of the IAs; what is the relationship between the market value of IAs and companies? what is the gap between the fair and market value of the companies on the securities market? and so on. However, the vast majority of such studies are related to other countries: the United States, Switzerland, England, France, India, Malaysia, and others. An important role is played by international organisations that, in order to increase the disclosure of financial 
information and its comparison between economic entities and other market participants, develop and improve common international accounting standards. In Lithuania, this area was explored in a fragmented way. In recent years, there are more studies showing that the topic is relevant in the world and in Lithuania.

The research aim. To estimate the value of IAs in the companies of Lithuania.

The research hypothesis. The value of IAs of non-financial information is higher than the value of IAs of financial information.

Design/methodology: In order to determine the IAs, the data of financial reporting of the period 2009-2015 were analysed. The data of 18 companies of different activities, whose shares are listed on the Stock Exchange, were analysed. IAs value has determined using the financial method of IAs measurement (FiMIAM). Research methods: Elaboration, organisation, collation, integration, comparison, graphical modelling, generalisation. Financial analysis was performed using MS Excel.

\section{Literature Review}

Analysing the research, the main scientific approach was revealed on the theme problem of recognition and evaluation of intangible assets as intangible assets in the accounting. The recognition of IAs as IAs in the financial statements is considered complicated by the definition of this assets, that is, by identifying it, determining its value, proving future economic benefits and ensuring control. Most researchers (Lev 2003; Volkov, Garanina 2007; Jukaitytė-Sungailienè 2009; Crema, Nosella 2014; Svensson 2014; Kimouche, Rouabhi 2016, etc.) agree that the totality of IAs belonging to the company includes the integrity of the IAs, which is disposed by the need and purpose. However, the incompatibility lies with the possibility of accounting for these resources, using recognition criteria in accordance with generally accepted accounting standards. It is precisely because of conservative accounting standards that most IAs are not accounted for and are not reflected in the financial statements. Only a small part of the IAs account is recognised, measured and disclosed as IAs. Other scientists (Shah, Khedkar 2006; Sofian et al. 2011; Stankevičienè, Liučvaitienè 2012; Jaara, Elkotayni 2016) confirm that most companies account IAs as expenses, whilst the costs necessary to form these assets are regarded as spending of that period, resulting in a decrease in owners personal capital. Notation of IAs together with other company's expenses has a direct impact on companies' results: profit and taxes. A similar approach is taken by scientists (Lönnqvist, Tech 2002; Shah, Khedkar 2006; Lin, Tang 2009;. Wight 2009; Sharma 2012; Kimouche, Rouabhi 2016; Ifeanyi, Caroline 2016) who claim that recognition of IAs has not yet been sufficiently investigated, and therefore, the estimation of IAs is considered an even more complex task, resulting in the gap between true and present value. Although various methods are created for valuation of IAs (Surroca, Tribo, Waddock 2006; Shah, Khedkar 2006; Wight 2009; Abhijeet, Richa 2010; Passard, cKenna, Krishnan 2012; Gamayuni 2015, etc.), however, the problem is due to the fact that most methods are difficult to apply in empirical studies.

The concept of IAs is a main subject of scientific discussion. Analysing the definitions and descriptions of the concept of IAs presented by scientists, it was noticed that this concept was interpreted differently, without consideration of the scientific research aspect. IAs can be described as assets that are based mainly on the information and knowledge (Sacui, Szatmary 2015). IAs help to build and to increase a value of company (Andriessen 2005; Garanina, Pavlova 2011; Crema, Nosella 2014). IAs make it possible to expect economic benefits in the future (Blair, Wallman 2003; Volkov, Garanina 2007; Villanueva 2011; Vidrascu 2015). Intangible assets play an important role in maintaining the competitive advantage of a company (Lev 2001; Ipate, Parvu 2016). Intangible assets consist from intangible resource, which belong and used according to the purpose in the company (Crema, Nosella 2014, Svensson 2014; Kimouche, Rouabhi 2016).

Analysis of the definitions of IAs shows that the concept of IAs is related to the period and, therefore, it was interpreted differently. In 1987, IAs were interpreted as knowledge assets. From 1990 to 1997, these were interpreted as core competencies, absorptive capability, intangibles and so on. In 1997, 
these were started to be used in the concept of the IAs. In 2000, IAs were implied as an intellectual capital (Table 1).

Table 1. Interpretation of the concept of intangible assets from the field of science

\begin{tabular}{|c|c|c|c|c|}
\hline \multirow{2}{*}{ Authors } & \multicolumn{4}{|c|}{ Science field } \\
\hline & Finance & Economics & Management & Law \\
\hline $\begin{array}{l}\text { Lev 2003; } \\
\text { Mackevičius, Jarmalaitė } \\
\text { 2011; } \\
\text { Ramanauskaite 2013; } \\
\text { Husnah et al 2013; } \\
\text { Gamayni 2015 }\end{array}$ & $\begin{array}{l}\text { Intangible } \\
\text { assets; } \\
\text { invisible } \\
\text { assets; } \\
\text { intangibles }\end{array}$ & $\begin{array}{l}\text { Knowledge assets; } \\
\text { intellectual assets; } \\
\text { knowledge capital; } \\
\text { intellectual } \\
\text { knowledge }\end{array}$ & $\begin{array}{l}\text { Intellectual capital; intangible } \\
\text { resources; intangible activities; } \\
\text { immaterial values; intangible } \\
\text { investment; organisation } \\
\text { intellectual capital }\end{array}$ & $\begin{array}{l}\text { Intellectual } \\
\text { capital; } \\
\text { intellectual } \\
\text { property }\end{array}$ \\
\hline Dumitrescu 2012 & \multicolumn{4}{|c|}{$\begin{array}{l}\text { Development of intangible assets: } 1987, \text { knowledge capital, invisible assets; } 1990, \text { core } \\
\text { competencies, architectural knowledge, absorptive capability; 1991, organizational } \\
\text { memory; 1992, intangible resources, combinative capabilities; 1995, strategic assets, core } \\
\text { capabilities; 1997, intangible assets; 2000, intellectual capital }\end{array}$} \\
\hline
\end{tabular}

The concept of IAs is usually used in the financial science. In economics studies, this concept is often interpreted as knowledge assets. But most scientists identify IAs as a part of intellectual capital in the management science. And this interpretation of the term can also be found in the fields of economics and law. This forms incorrect approach to the using of the concept of IAs. Pursuing to avoid ambiguities, hereby we offer to form the definition of IAs, highlighting the essential exclusivities of such assets: (1) The content of IAs is formed by intangible resources owned by an enterprise; (2) the value of IAs is disclosed recognising or not recognising IAs as assets in accounts; (3) the economic benefit of IAs is established by the created added value in the performance of an enterprise; (4) the economic benefit of IAs determines changes in the market value of an enterprise.

In order to maintain a competitive advantage and enhance value of the shares, the real structure of IAs in the company is very important. Shortage of information on IAs and the use of structure of its potential make it possible to manipulate the results of traditional financial accounting, whilst investors and other market participants are not reached by objective information reflecting real state of financial information of organisation. The acknowledgement of IAs and its accounting for the balance sheet is considered to be difficult and complicated. In most cases, the costs incurred by companies that are not accounted as IAs are included in either cost of production or recognised as operating expenses, thus reducing not only the quality of accounting information but also the property of the owners published in the financial statements. Combining traditional historical pricing and fair value pricing systems, it is possible to determine not only the value of IAs but also the flexibly adjustable changes in market prices. The theory of normative accounting is closely related to the general accounting principles, because the estimation value of IA depends on a properly chosen pricing policy that is necessary to disclose the true value of the intangible asset. The requirements of the general accounting principles for determining the value of IA do not always correspond to the real situation and cannot always be applied to the accounts of companies. For this reason, the value of IA involves two main accounting segments: accounted and non-accounted by IAs. The greater part of IAs is non-accounted because most of the IAs are written down to operating expenses. Owing to strictly regulated legislation, the most important part of accounting information remains incomplete information for consumers. The accounting disclosure aspects are analysed by the positive accounting theory, which emphasizes the relationship between accounting information and stock price developments. Publicly disclosed information is regulated by the general accounting principles (GAP) and is, therefore, reflected in the company's balance sheet as the value of the financial information intangible asset (FINT). In contrast, non-public information is associated with the value of non-financial information intangible assets (NINT).

\section{Methodology}

Stage 1. Business choice. To determine the research size, the following criteria were chosen: company's market value, date of listing, industry, set of financial statements, annual reports, FINT. 
The study uses data from 18 companies' financial statements and annual reports. The financial and non-financial information presented in these reports is considered as the main financial source. The value of IAs of financial information is the main criterion that led to the choice of 18 companies, because it is important for the evaluation of the value of IAs of non-financial information. However, the value of IAs of financial information of others companies was not available, and for this reason, other companies cannot appear in the researches. In order to perform a comparative analysis, different industries were selected for research and grouped into two large groups: manufacturing and services. The size of research was found to consist of nine services and nine manufacturing enterprises. This grouping of companies was not chosen a random because the measurement of the value of IAs is depended on the activities of different sectors. The main activities of the services group are telecommunications, financial, industrial and utilities. The main activities of the group of manufacturing companies include the production and marketing of food and beverages, clothing, textiles, household paper, alcohol and so on.

Stage 2. Components of intangible assets. The second stage of the research shows the way of structuring the IAs (Figure 1).

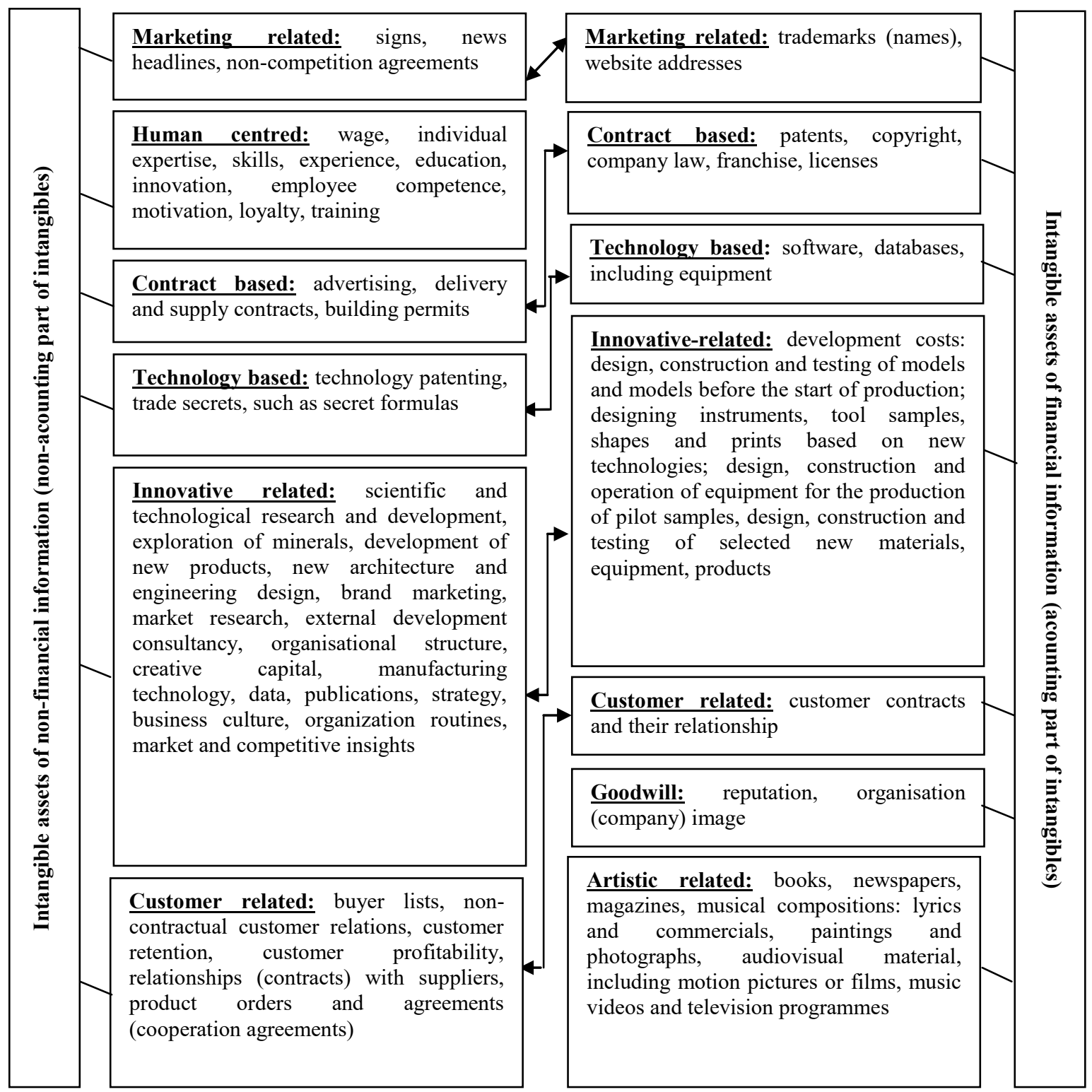

Fig. 1. Classification of the general intangible assets (Source: author's compilation) 
Depending on the suggestions of scientists to elements of the IAs and their sub-elements, the randomised sampling method is applied. There were selected 57 sub-elements of IAs, which are grouped into 8 main elements of IAs. According to the principles of general accounting, a classification of IAs has been prepared, which consists in two parts of assets: accounting and nonaccounting.

Stage 3. Determination of the value of intangible assets of financial information. In calculating the value of FINT, it was chosen to adapt the historical pricing system. Researchers, using empirical evidence to determine the impact of an IA on the market value of companies, most often used the balance sheet value at the end of the year. The carrying amount is the cost of acquisition of the IA during the period, which is reduced by writing off, liquidation or sale of assets and amortisation amount. The value of FINT that is used in the company's operations during the accounting year is higher and the carrying amount at the end of the year reflects the reduced value of the asset. In the opinion of the author, the amortisation amount represents the part of the value of the IAs that was used during the accounting year, which determined the market value of the company. It is proposed to calculate the value of IAs of financial information in the following sequence:

$$
F I N T_{i t}=N T B V_{\text {it }}+N T A_{i t}(1)
$$

where

$F I N T_{i t}$ is the value of IAs of financial information of the company at the accounting year, in euros;

$N T B V_{\text {it }}$ is the balance value of IAs of the company at the end of the accounting year, in euros;

$N T A_{i t}$ is- the value of amortisation of IAs of the company at the accounting year, in euros.

Stage 4. Determination of the value of intangible assets of non-financial information. The financial method of IAs measurement is to calculate the value of IAs of non-financial information (FiMIAM) (Rodov, Leliaert 2002). This method is chosen for the following reasons: (1) The structure of the method and the logic of its application are clear; (2) all IAs are valued at the monetary unit of measurement; (3) the results are compared with each other. This method consists of 6 steps:

Step 1. When seeking to identify the value of non-financial information of IAs in monetary terms, the author proposes a market value (RV) and equity relative index (NK) supplement with the financial information of IAs index (FINT). The value of financial information of IA shows the part of the assets recorded, but it includes the historical price, which varies from time to time on the market. In the absence of an active asset market, it would be difficult to accurately determine the value of nonfinancial information assets. The proposed relative index allows disclosure of the value of nonfinancial information on an IA at market value; in other words, it shows the value of an IA that has not been recognised on the market:

$$
N I N T_{i t}=\frac{R V_{i t}}{N K_{i t}} \times F I N T_{i t}
$$

where

$N I N T_{i t}$ is the value of IA of non-financial information of the company at the accounting year, in euros;

$R V_{i t}$ is the market value of the company at the accounting year, in euros;

$N K_{i t}$ is the value of owners' equity of the company at the accounting year, in euros;

$F I N T_{i t}$ is the value of IA of financial information of the company at the accounting year, in euros. 
Step 2. In accordance with the second step of the method, the quantitative content analysis method was chosen to identify the IAs of the non-financial information (Table 2).

Table 2. Method of quantitative content analysis (Source: author's compilation)

\begin{tabular}{|c|c|c|}
\hline Steps & Indicator & Description \\
\hline 1 & $\begin{array}{l}\text { The research sample and } \\
\text { period }\end{array}$ & $\begin{array}{l}\text { Financial statements, annual reports, additional information for } \\
\text { investors of } 18 \text { companies. Research period: } 2009-2015\end{array}$ \\
\hline 2 & $\begin{array}{l}\text { The object of research of } \\
\text { intangible assets of the } \\
\text { non-financial information }\end{array}$ & $\begin{array}{l}\text { Elements for the } 7 \text { intangible assets, consisting of } 46 \text { sub-elements : } \\
\text { (a) marketing related, 3; (b) human centred, 10; (c) contract based, } \\
3 \text {; (d) technology based, 2; (e) innovative related, 17; (f) customer } \\
\text { related, } 6 ;(\mathrm{g}) \text { artistic related, } 5\end{array}$ \\
\hline 3 & The units of measurements & $\begin{array}{l}\text { 1. Text information tools: sentences, phrases, messages and other } \\
\text { text; } \\
\text { 2. Visual media tools: paintings, graphs, charts and others }\end{array}$ \\
\hline 4 & $\begin{array}{l}\text { The scale of assessment of } \\
\text { intangible assets of the } \\
\text { non-financial information }\end{array}$ & $\begin{array}{l}\text { Nominal scale (qualitative data classification) selected for the } \\
\text { assessment of variables: } 0 \text {, neutral/none; } 1 \text {, not very important/is; } 2 \text {, } \\
\text { significant/is; 3, very significant/continuously improved and } \\
\text { developed }\end{array}$ \\
\hline 5 & $\begin{array}{l}\text { The coding system of } \\
\text { elements of intangible } \\
\text { assets of the non-financial } \\
\text { information }\end{array}$ & $\begin{array}{l}\text { According to the coding system of intangibles assets of non- } \\
\text { financial information, elements of assets that have been assigned } \\
\text { the appropriate scores were identified (in step 4) }\end{array}$ \\
\hline
\end{tabular}

Step 3. On the basis of the third step of the FiMIAM method, the weight assigned to the element of IAs of the non-financial information is calculated and expressed as a percentage:

$$
\begin{gathered}
\sum X_{i t}=a_{1}+a_{2} \ldots \ldots a_{n} ; \sum n_{i t}=X_{1}+X_{2} \ldots \ldots . . X_{n} ; \\
\text { NINTE }_{i t}=\frac{\sum X_{i t}}{\sum n_{i t}} \times 100 \%
\end{gathered}
$$

where

$N I N T E_{i t}$ is the number of elements of the IAs of non-financial information at the accounting year, $\%$

$\sum X_{i t}$ is the total amount of the unit of elements of the company at the accounting yeas;

$a_{1}+a_{2} \ldots \ldots . a_{n}$ is the number of the unit of sub-elements of the company at the accounting year;

$X_{1}+X_{2} \ldots \ldots \ldots X_{n}$ is the number of the unit of elements of the company at the accounting year;

$\sum n_{i t}$ is the total amount of elements at the accounting year.

Step 4. In the dissertation, the coding system is based on existing types of the IAs of nonfinancial information by the company. The planned data is not included in the contents of the IAs of non-financial information during the time of research. It is suggested to calculate the results obtained according to the assessment scale developed by Janis and Fadner (1965): $f=$ significant number of units; $u=$ insignificant number unit; $r=$ important number of units $=u+f+$ neutral number unit; $t=$ total number of units $=r+$ unimportant number of units. On the basis of the stated calculation logic, 
the system of points of the IAs of non-financial information, which is evaluated on a scale from 0 to 3 is compiled.

Step 5. This step is designed to calculate the IAs of non-financial information:

$$
N I N T E V_{i t}=N I N T_{i t} \times N I N T E_{i t}
$$

where

NINTE $V_{i t}$ is the value of elements of the IAs of non-financial information at the accounting year, in euros;

$N I N T_{i t}$ is the value of elements of the IAs of non-financial information of the company at the accounting year, in euros;

$N I N T E_{i t}$ is the number of elements of the IAs of non-financial information at the accounting year, $\%$.

Step 6 (Stage 5). Calculation of the value of general intangible assets. The fifth study stage of the theoretical model includes the sixth step of the method, which specifies the calculation sequence for the value of general IAs:

$$
B N T_{i t}=N I N T_{i t}+F I N T_{i t}
$$

where

$B N T_{i t}$ is the value of general IAs of the company at the accounting year, in euros;

$N I N T_{i t}$ is the value of elements of the IAs of non-financial information of the company at the accounting year, in euros;

$F I N T_{i t}$ is the value of IA of financial information of the company at the accounting year, in euros;

The value of general IAs $B N T_{i t}$ consists in two parts of assets: financial and non-financial information. The value of general IAs is calculated using different methods of evaluation. This value is calculated by adding the value of the IAs of financial information FINT to that of non-financial information $N I N T_{i t}$. The value of general IAs is defined as the fair value of IAs (32 GAP 2014).

The main limitation of this research. This methodology is suitable for listed companies but may also be used by others with certain reservation: for the calculation of non-financial information for IAs, one should choose another valuation method or a relative index, between the market value and the equity value (RV/NK), should be changed to the relative value of the business value and equity value (VV/NK).

\section{Results}

On the basis of the analysis of IAs, the elements of recognition of assets were disclosed, which revealed the peculiarities of the structure and value of the IAs of financial and non-financial information of Lithuanian companies. According to the results of research, in most of the companies of Lithuania, the value of IAs of financial information consists of elements that are related to intangibles of technology-based, contract-based and other assets. This includes the most part of IAs of financial information in the companies of Lithuanian. A little less recorded are the marketing related, 
customer related and goodwill. As expected, innovative-related assets are recognised and accounted in the balance sheet very rarely (Table 3 ).

Table 3. The intangible assets of financial information of Lithuanian companies according to the elements for 2009-2015, in thousand euros

\begin{tabular}{|c|c|c|c|c|c|c|c|c|c|c|c|c|c|c|}
\hline \multirow{2}{*}{ Companies } & \multicolumn{2}{|c|}{$\begin{array}{c}\text { Marketing } \\
\text { related }\end{array}$} & \multicolumn{2}{|c|}{ Human centred } & \multicolumn{2}{|c|}{$\begin{array}{l}\text { Technology } \\
\text { based }\end{array}$} & \multicolumn{2}{|c|}{$\begin{array}{c}\text { Innovative } \\
\text { related }\end{array}$} & \multicolumn{2}{|c|}{$\begin{array}{c}\text { Customer } \\
\text { related }\end{array}$} & \multicolumn{2}{|c|}{ Goodwill } & \multicolumn{2}{|c|}{ Other assets } \\
\hline & 2009 & 2015 & 2009 & 2015 & 2009 & 2015 & 2009 & 2015 & 2009 & 2015 & 2009 & 2015 & 2009 & 2015 \\
\hline Telia Lietuva & 0.0 & 0.0 & 4,651 & 1,577 & 7291 & 8,172 & 0.0 & 0.0 & 0.0 & 0.0 & 1,505 & 3,137 & 527 & 3,711 \\
\hline $\begin{array}{l}\text { Lietuvos } \\
\text { dujos }\end{array}$ & 0.0 & 0.0 & 735 & 468 & 705 & 422 & 0.0 & 0.0 & 0.0 & 0.0 & 0.0 & 0.0 & 1,708 & 686 \\
\hline Lesto & 0.0 & 0.0 & 0.0 & 42 & 3167 & 3,115 & 0.0 & 0.0 & 0.0 & 0.0 & 0.0 & 0.0 & 15 & 245 \\
\hline $\begin{array}{l}\text { Lietuvos } \\
\text { energija }\end{array}$ & 0.0 & 0.0 & 10,588 & 16,44 & 968 & 523 & 0.0 & 0.0 & 0.0 & 0.0 & 0.0 & 0.0 & 39 & 17 \\
\hline City Service & 0.0 & 0.0 & 0.0 & 0.0 & 0.0 & 0.0 & 0.0 & 0.0 & 16,54 & 1,086 & 10,94 & 9,304 & 608 & 3,911 \\
\hline $\begin{array}{l}\text { Klaipėdos } \\
\text { nafta }\end{array}$ & 0.0 & 0.0 & 0.0 & 0.0 & 45 & 1,107 & 0.0 & 0.0 & 0.0 & 0.0 & 0.0 & 0.0 & 0.0 & 0.0 \\
\hline Invalda INVL & 0.0 & 0.0 & 0.0 & 4226 & 190 & 36 & 0.0 & 0.0 & 2,845 & 0.0 & 0.0 & 90 & 25 & 0 \\
\hline $\begin{array}{l}\text { Šiaulių } \\
\text { bankas }\end{array}$ & 0.0 & 0.0 & 0.0 & 0.0 & 294 & 1,296 & 0.0 & 0.0 & 0.0 & 0.0 & 0.0 & 2,752 & 0.0 & 0.0 \\
\hline $\begin{array}{l}\text { Kauno } \\
\text { energija }\end{array}$ & 0.0 & 0.0 & 0.0 & 148 & 93 & 0.0 & 0.0 & 0.0 & 0.0 & 0.0 & 0.0 & 0.0 & 0.0 & 1,245 \\
\hline $\begin{array}{l}\text { Vilniaus } \\
\text { degtinè }\end{array}$ & 5,752 & 2,65 & 12 & 0.0 & 167 & 172 & 0.0 & 0.0 & 0.0 & 0.0 & 0.0 & 0.0 & 0.0 & 0.0 \\
\hline $\begin{array}{l}\text { Pieno } \\
\text { žvaigždès }\end{array}$ & 0.0 & 0.0 & 0.0 & 0.0 & 241 & 116 & 0.0 & 0.0 & 0.0 & 0.0 & 97 & 0.0 & 1,011 & 0.0 \\
\hline Rokiškio sūris & 0.0 & 0.0 & 0.0 & 0.0 & 123 & 21 & 0.0 & 0.0 & 611 & 0.0 & 0.0 & 0.0 & 0.0 & 0.0 \\
\hline $\begin{array}{l}\text { Panevèžio } \\
\text { statybos } \\
\text { trestas }\end{array}$ & 0.0 & 0.0 & 0.0 & 0.0 & 89 & 122 & 0.0 & 0.0 & 0.0 & 0.0 & 35 & 31 & 6 & 32 \\
\hline $\begin{array}{l}\text { Dvarčioniu } \\
\text { keramika }\end{array}$ & 0.0 & $\begin{array}{c}1,85 \\
0\end{array}$ & 0.0 & 0.0 & 16 & 0.0 & 0.0 & 0.0 & 0.0 & 0.0 & 0.0 & 0.0 & 0.0 & 0.0 \\
\hline $\begin{array}{l}\text { Vilniaus } \\
\text { baldai }\end{array}$ & 0.0 & 0.0 & 0.0 & 0.0 & 133 & 41 & 0.0 & 0.0 & 0.0 & 0.0 & 0.0 & 0.0 & 188 & 118 \\
\hline Snaigé & 0.0 & 0.0 & 0.0 & 0.0 & 46 & 121 & 1,652 & 1,854 & 0.0 & 0.0 & 0.0 & 0.0 & 2,352 & 0.0 \\
\hline $\begin{array}{l}\text { Grigeo } \\
\text { Grigiškès }\end{array}$ & 0.0 & 0.0 & 659 & 639 & 55 & 2,345 & 0.0 & 0.0 & 0.0 & 0.0 & 0.0 & 0.0 & 0.58 & 240 \\
\hline Apranga & 0.0 & 0.0 & 213 & 323 & 310 & 360 & 0.0 & 0.0 & 0.0 & 0.0 & 0.0 & 0.0 & 0.0 & 0.0 \\
\hline
\end{tabular}

The results of the research show that it is not complicated to adapt the main criteria for recognising IAs, economic benefits, value and control (International accounting standard, 38 (IAS 38), when it comes to accounting for elements of technology, contract and other assets. The application of the general accounting standards in practice is quite complicated when it comes to accounting for elements of marketing, customer and innovative assets. Goodwill is only recorded when there is a transaction between companies: the price paid by the buyers for the shares of the company exceeds the value of the acquired net assets of the company (National Accounting Standard, 14 (NAS 14 2013)).

The disclosure of components of the IAs of financial information (FINT) of companies in Lithuania contains detailed analysis of the sub-elements of these assets (Figure 2). 


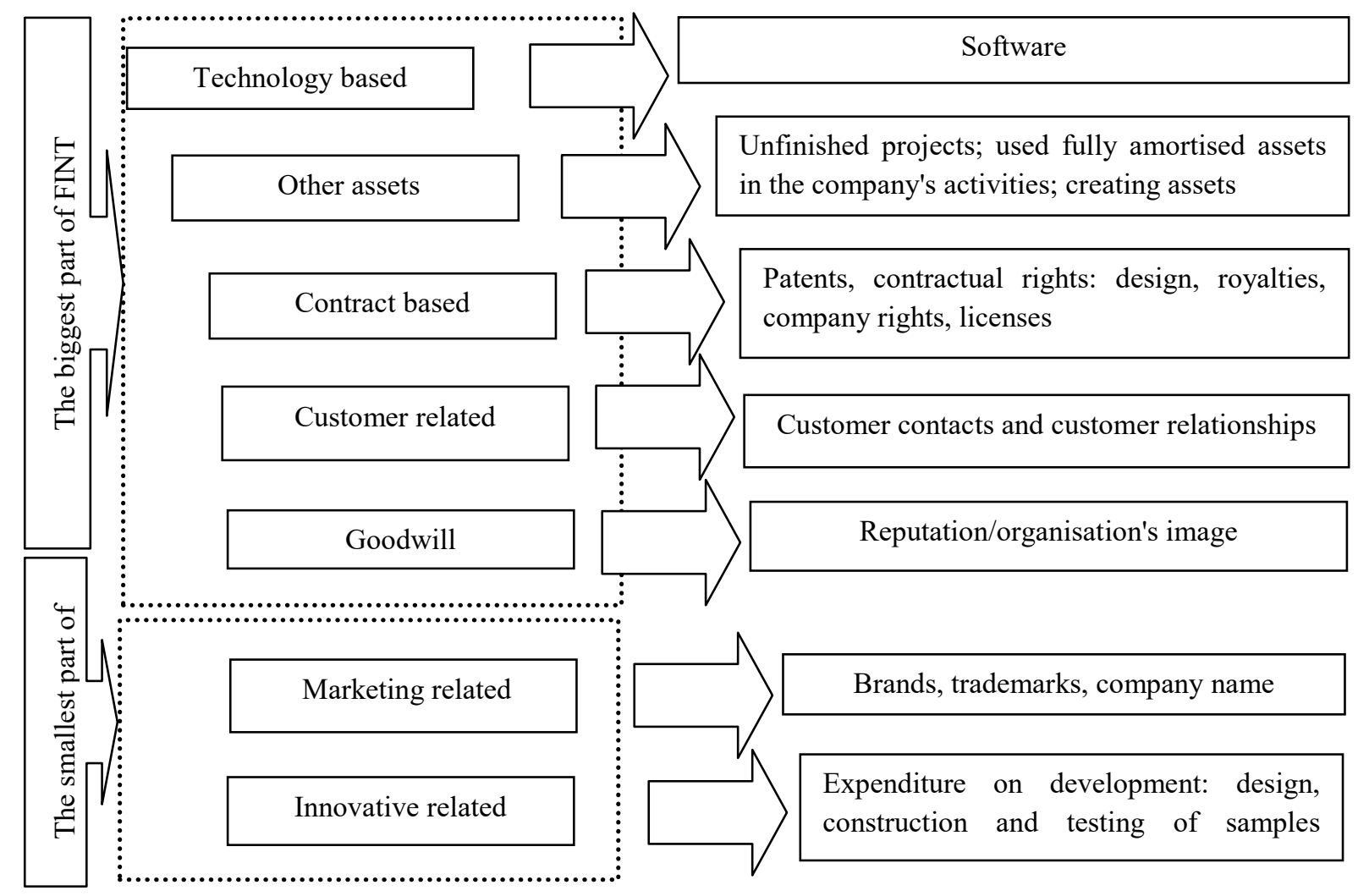

Fig. 2. Sub-elements of the intangible assets of financial information of companies

Most of FINT structures consisted of sub-elements related to the acquisition of software, the implementation of unfinished projects, assets that were fully amortised but still used in the company's activities, corporate rights, patents, licenses, reputations and so on. One of the most important elements of the property is the goodwill. The value of goodwill as assets depends on transactions between companies, their mergers and acquisitions. Practical experience in business, reputation, image, clients, brands and so on, acquired by other companies, also plays an important position in FINT structure. Another important asset element is the customer-related asset. This type of asset increased the volume of FINT when contracts were concluded with customers and suppliers of Lithuanian or foreign companies.

The smallest part of this asset was made up of marketing and innovative assets. Trademarks, company names and development costs are resources that relate to the company's ability to exploit the growth potential of the market.

On the basis of the $4^{\text {th }}$ stage of the research methodology, the value of the IAs of non-financial information was determined by applying the financial method of IAs measurement (FiMIAM) (Table $4)$.

Table 4. The intangible assets of non-financial information of Lithuanian companies according to the elements for 2009-2015, in thousand euros

\begin{tabular}{|c|c|c|c|c|c|c|c|c|c|c|c|c|c|c|}
\hline \multirow{2}{*}{ Companies } & \multicolumn{2}{|c|}{$\begin{array}{l}\text { Marketing } \\
\text { related }\end{array}$} & \multicolumn{2}{|c|}{$\begin{array}{l}\text { Human } \\
\text { centred }\end{array}$} & \multicolumn{2}{|c|}{ Contract based } & \multicolumn{2}{|c|}{$\begin{array}{l}\text { Technology } \\
\text { based }\end{array}$} & \multicolumn{2}{|c|}{$\begin{array}{c}\text { Innovative } \\
\text { related }\end{array}$} & \multicolumn{2}{|c|}{ Customer related } & \multicolumn{2}{|c|}{ Artistic related } \\
\hline & 2009 & 2015 & 2009 & 2015 & 2009 & 2015 & 2009 & 2015 & 2009 & 2015 & 2009 & 2015 & 2009 & 2015 \\
\hline Telia Lietuva & 0.0 & 2,601 & 4,511 & 7,804 & 0.0 & 0.0 & 0.0 & 0.0 & 11,27 & 18,208 & 4,511 & 13,006 & 0.0 & 0.0 \\
\hline
\end{tabular}




\begin{tabular}{|c|c|c|c|c|c|c|c|c|c|c|c|c|c|c|}
\hline $\begin{array}{c}\text { Lietuvos } \\
\text { dujos }\end{array}$ & 0.0 & 0.0 & 0.0 & 0.0 & 87 & 0.0 & 0.0 & 0.0 & 479 & 415 & 479 & 553 & 0.0 & 0.0 \\
\hline Lesto & 59.6 & 0.0 & 477 & 1,365 & 60 & 227 & 36 & 0.0 & 418 & 2,047 & 179 & 1,137 & 60 & 0.0 \\
\hline $\begin{array}{c}\text { Lietuvos } \\
\text { energija }\end{array}$ & 917 & 0.0 & 2,619 & 9,835 & 0.0 & 0.0 & 0.0 & 0.0 & 2,619 & 6,772 & 437 & 1,229 & 0.0 & 0.0 \\
\hline City Service & 2,658 & 0.0 & 13,29 & 2,347 & 2,658 & 1,173 & 2,658 & 0.0 & 15,95 & 5,867 & 10,633 & 1,173 & 0.0 & 0.0 \\
\hline $\begin{array}{c}\text { Klaipédos } \\
\text { nafta }\end{array}$ & 0.0 & 0.0 & 10 & 251 & 3 & 108 & 3 & 0.0 & 6 & 287 & 10 & 144 & 0.0 & 0.0 \\
\hline $\begin{array}{c}\text { Invalda } \\
\text { INVL }\end{array}$ & 0.0 & 0.0 & 747 & 1,327 & 373 & 332 & 0.0 & 332 & 933 & 995 & 560 & 332 & 0.0 & 0.0 \\
\hline $\begin{array}{l}\text { Šiaulių } \\
\text { bankas }\end{array}$ & 0.0 & 138 & 109 & 1,107 & 0.0 & 0.0 & 0.0 & 0.0 & 62 & 969 & 62 & 554 & 0.0 & 0.0 \\
\hline $\begin{array}{c}\text { Kauno } \\
\text { energija }\end{array}$ & 0.0 & 0.0 & 12 & 46 & 2 & 9 & 0.0 & 0.0 & 14 & 64 & 9 & 37 & 0.0 & 0.0 \\
\hline $\begin{array}{l}\text { Vilniaus } \\
\text { degtinè }\end{array}$ & 155 & 105 & 1,475 & 630 & 738 & 105 & 0.0 & 0.0 & 738 & 734 & 328 & 210 & 0.0 & 0.0 \\
\hline $\begin{array}{c}\text { Pieno } \\
\text { žvaigždès }\end{array}$ & 0.0 & 19 & 627 & 58 & 209 & 19 & 208 & 20 & 418 & 96 & 0.0 & 19 & 0.0 & 0.0 \\
\hline $\begin{array}{c}\text { Rokiškio } \\
\text { sūris }\end{array}$ & 26 & 0.4 & 129 & 2 & 26 & 0.0 & 0.0 & 0.0 & 231 & 5 & 77 & 2 & 0.0 & 0.0 \\
\hline $\begin{array}{c}\text { Panevėžio } \\
\text { statybos } \\
\text { trestas }\end{array}$ & 0.0 & 0.0 & 29 & 28 & 7 & 5 & 0.0 & 0.0 & 29 & 28 & 15 & 14 & 0.0 & 0.0 \\
\hline $\begin{array}{c}\text { Dvarčioniu } \\
\text { keramika }\end{array}$ & 0.0 & 0.0 & 5 & 72 & 1 & 48 & 0.0 & 0.0 & 6 & 72 & 1 & 24 & 0.0 & 0.0 \\
\hline $\begin{array}{l}\text { Vilniaus } \\
\text { baldai }\end{array}$ & 0.0 & 0.0 & 68 & 250 & 0.0 & 0.0 & 23 & 0.0 & 114 & 374 & 45 & 125 & 0.0 & 0.0 \\
\hline Snaigè & 105 & 151 & 526 & 754 & 104 & 149 & 104 & 150 & 631 & 905 & 210 & 452 & 0.0 & 0.0 \\
\hline $\begin{array}{c}\text { Grigeo } \\
\text { Grigiškes }\end{array}$ & 0.0 & 0.0 & 363 & 577 & 121 & 192 & 0.0 & 0.0 & 726 & 962 & 484 & 385 & 0.0 & 0.0 \\
\hline Apranga & 0.0 & 0.0 & 532 & 331 & 530 & 330 & 0.0 & 0.0 & 1,329 & 828 & 266 & 497 & 0.0 & 0.0 \\
\hline
\end{tabular}

The most value of the IAs of non-financial information has been elements that include innovativerelated, human-centred and customer-related assets. Companies had less technology-based, contractbased and marketing-related assets. Artistic-related assets are only found in one company (Lesto). Comparing the data from the beginning of 2009 till the end of 2015, it can be seen that the value of IAs of non-financial information is distributed unevenly in Lithuanian companies.

As shown in Figure 3, the sub-elements of the human-centred assets are distinguished from the whole. These assets include sub-elements that are based on the relationship between the employee and the company. Wages, education, experience, motivation and competence are the resources on which the company's prosperity and future depend. Innovative assets relate to (1) the development, updating and upgrading of new products; (2) the development of creative capital, modernisation of technological processes; (3) the strengthening competitiveness; (4) the growth of the company's value and so on. This type of asset consisted of the following main sub-elements: creative capital, organizational structure of business, strategy, market and competitiveness insights, the growth of which is associated with the implementation of innovative processes. However, research and development and its activities included a small proportion of innovative assets. The customer retention sub-element dominated the customer-related asset. Non-contractual customer relations, relations with suppliers, production orders and agreements constituted a smaller part of IAs of non-financial information. The value of advertisements was highlighted in the contract-based asset, and this sub-element remained at a similar level throughout the period under investigation. Technology patents are most distinguished in the technology-based assets. Trademarks dominated in the marketing-related assets. The smallest part of IAs of non-financial information consisted of artistic assets - books and music. 


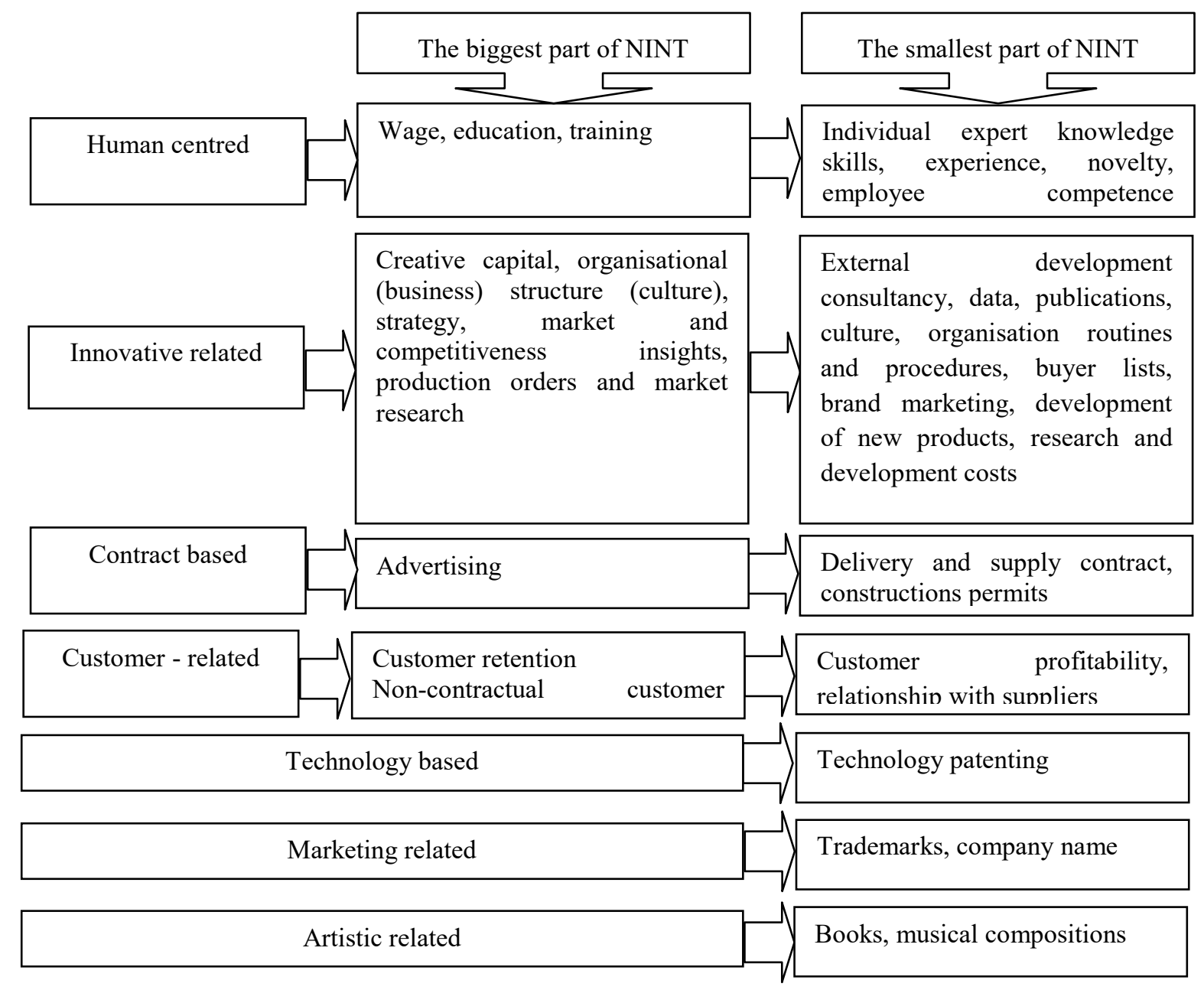

Fig. 3. Sub-elements of the intangible assets of non-financial information of companies

The value of general IAs (in the fifth stage of the research methodology) combines the values of IAs of financial and non-financial information. The analysis shows that the biggest gap between the value of IAs of financial and non-financial information was in the companies, which carried out the service activities: Telia Lietuva, City Service, Invalda INVL, Apranga and others (Table 5).

Table 5. The value of general intangible assets in the Lithuanian companies for 2009-2015, in million euros

\begin{tabular}{|c|c|c|c|c|c|c|c|c|c|c|c|c|c|c|}
\hline \multirow{2}{*}{ Companies } & \multicolumn{2}{|c|}{2009} & \multicolumn{2}{|c|}{2010} & \multicolumn{2}{|c|}{2011} & \multicolumn{2}{|c|}{2012} & \multicolumn{2}{|c|}{2013} & \multicolumn{2}{|c|}{2014} & \multicolumn{2}{|c|}{2015} \\
\hline & NINT & FINT & NINT & FINT & NINT & FINT & NINT & $\begin{array}{l}\text { FINT } \\
\end{array}$ & NINT & FINT & NINT & FINT & NINT & FINT \\
\hline Telia Lietuva & 20.3 & 14.0 & 32.5 & 17.3 & 23.6 & 15.3 & 29.0 & 14.7 & 34.1 & 17.2 & 37.6 & 15.6 & 41.6 & 16.6 \\
\hline Lietuvos dujos & 1.6 & 3.1 & 1.8 & 3.2 & 1.2 & 2.6 & 0.9 & 2.0 & 2.1 & 1.8 & 1.8 & 1.6 & 0.0 & 0.0 \\
\hline Lesto & 1.3 & 3.2 & 0.9 & 1.8 & 0.7 & 2.2 & 1.0 & 2.7 & 1.7 & 3.5 & 4.8 & 3.4 & 0.0 & 0.0 \\
\hline $\begin{array}{l}\text { Lietuvos } \\
\text { energijos } \\
\text { gamyba }\end{array}$ & 0.0 & 0.0 & 0.0 & 0.0 & 5.7 & 11.6 & 11.0 & 17.6 & 5.6 & 9.2 & 14.5 & 11.0 & 20.9 & 17.0 \\
\hline City Service & 47.8 & 28.1 & 80.6 & 41.4 & 53.2 & 44.2 & 40.0 & 36.4 & 25.3 & 27.1 & 22.1 & 27.1 & 10.6 & 14.3 \\
\hline Klaipèdos nafta & 0.03 & 0.0 & 0.2 & 0.2 & 0.2 & 0.2 & 0.4 & 0.5 & 0.3 & 0.5 & 0.5 & 0.7 & 0.8 & 1.1 \\
\hline Vilniaus degtiné & ND & ND & 3.0 & 5.9 & 2.0 & 3.8 & 2.0 & 3.5 & 3.3 & 3.2 & 2.6 & 3.0 & 1.8 & 2.8 \\
\hline Pieno žvaigždès & 1.5 & 1.3 & 2.9 & 1.5 & 2.5 & 1.2 & 3.0 & 1.5 & 2.3 & 1.0 & 1.8 & 0.9 & 0.2 & 0.1 \\
\hline
\end{tabular}




\begin{tabular}{|c|c|c|c|c|c|c|c|c|c|c|c|c|c|c|}
\hline $\begin{array}{l}\text { Panevėžio } \\
\text { statybos trestas }\end{array}$ & 0.1 & 0.1 & 0.1 & 0.1 & 0.0 & 0.1 & 0.1 & 0.1 & 0.1 & 0.2 & 0.1 & 0.2 & 0.1 & 0.2 \\
\hline $\begin{array}{l}\text { Dvarčioniu } \\
\text { keramika }\end{array}$ & 0.01 & 0.02 & 0.001 & 0.006 & 0 & 0.001 & 0 & 0.001 & 0 & 0.001 & 0 & 0 & 0.2 & 1.9 \\
\hline Vilniaus baldai & 0.3 & 0.3 & 0.3 & 0.2 & 0.2 & 0.1 & 0.1 & 0.1 & 0.6 & 0.2 & 1.1 & 0.2 & 0.7 & 0.2 \\
\hline Snaigè & 1.7 & 4.1 & 2.8 & 4.0 & 8.1 & 4.0 & 7.5 & 4.2 & 7.9 & 4.1 & 8.6 & 4.7 & 2.6 & 2.0 \\
\hline Invalda INVL & 2.6 & 3.1 & 6.2 & 3.5 & 3.6 & 4.3 & 3.4 & 4.0 & 4.2 & 3.1 & 3.1 & 3.8 & 3.6 & 4.4 \\
\hline Šiaulių bankas & 0.2 & 0.3 & 0.2 & 0.2 & 0.2 & 0.3 & 0.3 & 0.4 & 0.4 & 0.5 & 2.3 & 3.5 & 2.8 & 4.0 \\
\hline Rokiškio sūris & 0.5 & 0.7 & 0.2 & 0.2 & 0.3 & 0.4 & 0.2 & 0.4 & 0.2 & 0.4 & 0.2 & 0.3 & 0.01 & 0.02 \\
\hline Kauno energija & 0.04 & 0.09 & 0.01 & 0.09 & 0.01 & 0.08 & 0.01 & 0.05 & 0.01 & 0.07 & 0.2 & 1.5 & 0.2 & 1.4 \\
\hline $\begin{array}{l}\text { Grigeo } \\
\text { Grigiškès }\end{array}$ & 1.7 & 0.7 & 1.3 & 0.7 & 1.3 & 1.3 & 2.0 & 1.8 & 2.5 & 1.9 & 2.7 & 1.7 & 2.1 & 1.4 \\
\hline Apranga & 2.7 & 0.5 & 1.7 & 0.4 & 1.0 & 0.3 & 0.4 & 0.2 & 1.3 & 0.5 & 0.7 & 0.8 & 2.0 & 0.7 \\
\hline
\end{tabular}

The value of NINT for most companies is significantly higher than that of the FINT (FINT < NINT). This is due to the fact that the value of NINT depends on the market price, whilst the FINT value reflects the historical price. It goes without saying that this difference arises between historical and market prices. However, the value of NINT may increase and decrease based on the methodology for calculating this asset if the equity value significantly exceeds the market value (NK $>$ RV). Hence, the FINT value may be greater than the NINT value (FINT $>$ NINT). The data presented give a general indication of the true value of the IA, the disclosure of which determines the fluctuation of stock prices in the market.

\section{Conclusions}

After analysing the theoretical concepts of IAs, it has been established that the interpretation of this concept is presented and accepted in different directions from the point of view of science. Scientific discussions often arise from the content of the notion of IAs, because in the general sense the concept is perceived superficially, the essential aspects remain unaffected.

The essential differences in the definition of IAs are less significant in practice than their similarities in economic and management science, but they remain significant in terms of economic and financial sciences. As the concept of IAs is inaccurate in terms of content, the article proposes to formulate this definition in the light of the most important explicit features of the analysed assets: the economic significance of IAs, the future economic benefits of the asset, the added-value created and the company's market value growth potential.

The results of the study confirmed the IA valuation methodology, which allows companies to calculate the fair value of an IA, which will increase the market value of the share, remains an important aspect. When comparing firms, it was found that FINT was dominated by customer-related, contract-based and technology-based assets and goodwill. In NINT, innovative-related, customer-related and humancentred assets were relatively large in terms of total assets. The results of the research showed that one company is trying to reveal financial information more and others the non-financial information. This is because the proportion of IAs depends on the composition of the asset, which is related to the company's activities. The general IAs consisted primarily of elements that were innovative related, technology based, customer related and human centred. The results of the study showed the difference in the value of IAs of companies between financial and non-financial information. The value of NINT is higher than that of FINT. The reason is that value of FINT measured at cost price, which reflects the historical cost. The cost price is not competitive or cannot compete in the market. On the contrary, value of NINT has a positive and significant impact on the market value of companies. Value of NINT was measured at price of market, and it characterises the higher growth and effect on the market value of companies. 
Further direction of research development is the evaluation of the value of IAs based on the assessment methodology can be applied when researching the impact of IAs on the company's market.

\section{References}

Abhijeet, CH., Richa, G. (2010). Intellectual Capital Accounting. Advances In Management, 3 (9), 13-16.

Andriessen, D. (2005). Implementing the KPMG Value Explorer: Critical success factors for applying IC measurement tools. Journal of Intellectual Capital, 6, 474-488.

Blair, M., Wallman, S. (2003). The growing intangibles reporting discrepancy, Intangibles: management, measurement and reporting. Washington: Brooking Institution Press, John Hand and Baruch Lev (Ed), 449 468.

Crema, M., Nosella, A. (2014). Intangible assets management and evaluation: evidence from SMEs. Engineering Management journal, 26 (1), 8-14.

Dumitrescu, A. S. (2012). Intangible assets: are these resources sufficiently visible and properly controlled ?. Accounting and Management information systems, 11. (4), 545-563.

Gamayuni, R. R. (2015). The Effect of Intangible Asset, Financial Performance and Financial Policies on the Firm Value. International Journal of Scientific \& Technology Research, 4, 202-212.

Garanina, T., Pavlova, Y. (2011). Intangible assets and value creation of a company: Russian and UK evidence. Proceedings of the European conference on intellectual capital, 165-175.

Husnah, Subroto B. Aisjah, S., Djumahir (2013). Intangible Assets, Competitive Strategy and Financial Performance: Study on Rattan SMEs in Palu City of Central sulawesi (Indonesia). Journal of Business and Management, 7(4), 14-27.

Ifeanyi N., Caroline, O. (2016). Evaluating the Effect of Intangible Assets on Economic Value added of Selected Manufacturing Firms in Nigeria. European Journal of Business and Management, 8 (15).

Ipate, D. M., Parvu, I. (2016). The impact of intangible assets on companies in emerging markets. Economics, Management, and Financial Markert, 11 (1), 94-99.

Jaara, O. O., Elkotayni, K. A. R. (2016). The Impact of Intangible Assets Internally Developed on the Market Values of companies. A Field Study in the Pharmaceutical Companies in Jordan. Accounting and Finance Research, 5 (2), 154-163.

Janis, I. L., Fadner, R. H. (1965). The coefficient of imbalance. In H. D. Lasswell, N. Leites, \& associates (Eds.), Language of politics, Cambridge, MA: MIT Press, 153-169.

Jukaitytė-Sungailienè, A. (2009). Turto samprata Lietuvos civilinèje teisèje. Socialiniu mokslu studijos, 3(3), 213-227.

Kimouche, R., Rouabhi, A. (2016). The Impact of Intangibles on the Value Relevance of Accounting Information: Evidence from French Companies. Intangible Capital, 12 (2).

Lev B. (2003) Intangibles: Management, Measurement, and Reporting, Cwinto-Consulting, Moscow.

Lev, B. (2001). Intangibles: Management, Measurement and Reporting. Brookings Institute Press, Washington.

Lin, G. T. R., Tang, J. Y. H. (2009). Appraising Intangible Assets from the Viewpoint of Value Drivers. Journal of Business Ethics, 88 (4), 679-689.

Lonnqvist, A., Tech, L. (2002). Measurement of intangible assets - an analysis of key concepts. Frontiers of Ebusiness Research, 275-294.

Mackevičius, J., Jarmalaitè, J. (2011). Nematerialieji ištekliai kaip apskaitos objektas: samprata, pripažinimas ir klasifikavimas. Verslo ir teisés aktualijos, 6(2), 302-318.

Passard C. D., cKenna, K., Krishnan, V., (2012). Accounting for Human Capital: Is the Balance Sheet Missing Something? International Journal of Business and Social Science, 3 (12), 61-64.

Ramanauskaitè, A. (2013). Intelektinio kapitalo ịvertinimo ir pateikimo finansinèse ataskaitose modelis. Daktaro disertacija: Socialiniai mokslai, ekonomika. Vilniaus universitetas. 
Rodov, I., Leliaert, P. (2002). FiMIAM: financial method of intangible assets measurement. Journal of Intellectual Capital: Measuring intellectual capitalism, 3(3), 323-336.

Sacui V., Szatmary, M. C. (2015). Intangible Assets in Business Combinations. Review of International Comparative Management, 16 (3), 385-397.

Shah, T., Khedkar, A. (2006). Measuring intangible assets - Indian experience. Indian Institute of Planning and Management (IIPM) Ahmedabad, 1-23.

Sharma, N. (2012). Intangible Assets: A Study of Valuation Methods. BVIMR Management Edge, 5 (1), 61-69.

Sofian, S. Zaleha, S., Rasid, A., Mehri, M., Umar, M.S. (2011). Effect of recognition of intellectual capital on relevance of accounting information. Interdisciplinary journal of contemporary research in business institute of interdisciplinary business research, 3(2), 1654-1664.

Stankevičienè, A., Liučvaitienè, A. (2012). Intelektinio kapitalo vertinimo aspektai. Verslas: teorija ir praktika, 13(1), 79-93.

Surroca, J., Tribo, J. A., Waddock, S. (2006). Corporate responsibility and financial performance: the role of intangible resources. Strategic Management Journal. Strat. Mgmt, 31, 463-490.

Svensson, A. (2014). Voluntary Disclosure of Information on Intangibles in Corporate. Annual Reports Global Review of Accounting and Finance, 4 (1), 133-147.

Tarptautinis apskaitos standartas „Nematerialusis turtas“, Nr. 38, 2007.

Tarptautinis apskaitos standartas „Tikrosios vertès nustatymas“, Nr. 32, 2014.

Verslo apskaitos standartas „Verslo jungimai“, Nr. 14, 2013.

Vidrascu, P. A. (2015). Intangible Assets - Sustainable Economic Factors and New Creators of Value. Internal Auditing \& Risk Management, 1 (37), 65-75.

Villanueva, C. A. (2011). Towards a new model for evaluation of intangibles. Strategy document T01. Corporate Excellence.

Volkov, D., Garanina, T. (2007). Intangible Assets: Importance in the Knowledge-Based Economy and the Role in Value Creation of a Company. Electronic Journal of Knowledge Management, 5 (4), 539 - 550.

Wight, A. M. (2009). Building Intangible Resources: The Stickiness of Reputation. Corporate Reputation Review Volume, 12(1), 21-32. 